\title{
Is Copper an Inhibiting Factor for Primary Production in the Upwelling Waters of Cabo Frio?
}

\author{
Antônia G. Diniz ${ }^{a}$, Claudia Hamacher ${ }^{b}$, Angela de L. R. Wagener ${ }^{*, b}$ \\ and Eliane Gonzalez-Rodriguez ${ }^{c}$ \\ ${ }^{a}$ Instituto de Quimica, Universidade Federal Rural do Rio de Janeiro, Antiga Rodovia Rio-São Paulo, km 47, \\ 22851-900 Soropédica - RJ, Brazil \\ ${ }^{b}$ Departamento de Quimica, Pontificia Universidade Católica do Rio de Janeiro, R. Marquês de S. Vicente, 225, \\ 22453-900 Rio de Janeiro - RJ, Brazil \\ ${ }^{c}$ Instituto Estudos do Mar Almte. Paulo Moreira, Rua Kioto, 253, 28930-000 Arraial do Cabo - RJ, Brazil
}

\begin{abstract}
O objetivo deste trabalho foi testar a hipótese de que espécies inorgânicas de cobre poderiam atuar como um fator inibidor da produção primária nas águas de ressurgência de Cabo Frio. Para tal, amostras de água foram coletadas de quatro profundidades diferentes em três estações costeiras ao largo de Cabo Frio, nas quais determinou-se a concentração de espécies macronutrientes, pH, oxigênio dissolvido, alcalinidade, concentração de material particulado, clorofila a, produção primária, especiação de cobre $(\mathrm{Cu}(\mathrm{II})$ e $\mathrm{Cu}(\mathrm{I}))$ e a capacidade de complexação. Os resultados indicam que a taxa de fotossíntese em águas ricas em nutrientes, mas com mais altas concentrações de cobre e baixas capacidades de complexação, são significantemente reduzidas. $\mathrm{Cu}(\mathrm{I})$ constituiu de 2 a $15 \%$ do cobre total, embora não se tenham encontrado evidências de que a sua produção fotoquímica afete a produtividade primária.
\end{abstract}

The goal of the present work was to test the hypothesis that inorganic species of copper may inhibit primary production in upwelling waters from the Cabo Frio region. Water samples were collected from four different depths up to $50 \mathrm{~m}$ at three stations of Cabo Frio and nutrient concentration, $\mathrm{pH}$, dissolved oxygen, alkalinity, seston, chlorophyll a, primary production, NPP, copper speciation, $\mathrm{Cu}(\mathrm{II})$ and $\mathrm{Cu}(\mathrm{I})$ and complexing capacity were determined. The results indicate that the rate of photosynthesis in nutrient rich waters with higher copper content and lower complexing capacity is significantly reduced. $\mathrm{Cu}(\mathrm{I})$ made up $2-15 \%$ of the total copper, however, there was no evidence to suggest that the photochemical production of $\mathrm{Cu}(\mathrm{I})$ affects NPP.

Keywords: primary production, copper speciation, upwelling waters

\section{Introduction}

Copper (II) ions ${ }^{1,2}$ and possibly inorganic copper complexes $^{3}$ are powerful inhibitors of phytoplankton activity even at very low concentrations. Copper (II) ions show a high affinity for ligand sites at the cell membrane and once bound, they block the transfer of other essential ions to the cell. ${ }^{4}$ The fraction of "free" copper (II) (inorganic species) present in seawater is variable and depends on the availability of organic ligands.

Upwelling ocean waters that resided for long periods well below the photic zone are usually very poor in organic substrates. Although they are rich in macronutrients, the

* e-mail: angela@rdc.puc-rio.br upwelled waters also carry a load of trace elements as "free" ions, which are able to adversely affect the initiation of primary production. ${ }^{5-7}$ As early as 1969, Barber and Ryther ${ }^{4}$ suggested that the increase in the productivity index observed in upwelled waters that resided longer in the surface (the so-called biological conditioning) should be attributed to the increase in the amount of biogenic organic ligands.

Although more than 30 years have elapsed since the original hypothesis by Barber ${ }^{5}$ and co-workers, no convincing demonstration of organic conditioning of dissolved copper in upwelling waters has been presented to date. However a number of experiments carried out under controlled conditions have been reported to understand the role of copper speciation on phytoplankton growth. ${ }^{3,8,9}$ 
As demonstrated by Moffet and Zika, ${ }^{10}$ even in organic rich waters, a significant fraction of "free" $\mathrm{Cu}$ (II) ions may exist resulting from the photodegradation of organic complexes through the mechanism of ligand-metal charge transfer. This photochemical reaction can occur in the photic zone producing $\mathrm{Cu}$ (I) first, which is then re-oxidized to $\mathrm{Cu}(\mathrm{II})$. The half time for the reaction is estimated to be larger than $6 \mathrm{~h}$, with decreasing copper complexing capacity due to oxidation of the ligands.

In spite of the recognized influence of the South Atlantic Central Waters (SACW) upwelling on the production of the coastal region of Rio de Janeiro and S. Paulo (Brazil), ${ }^{11-16}$ few studies have been conducted on the chemistry of these nutrient rich waters. Data on metal speciation of the Brazilian coast are non-existent. A survey on trace metal levels was conducted in the 1980's by Kremling and Wagener ${ }^{17}$ along the south coast of the State of Rio de Janeiro.

The maximum of SACW upwelling occurs at Cabo Frio when east, northeast and north winds displace surface waters allowing the flow of deeper and cooler water masses to the surface. The phenomenon is seasonal (more pronounced in period between September-April) and is characterized by rapid shifts between upwelling and downwelling. ${ }^{15}$ Compared to other major upwellings, for instance in western Africa and western South America, the Cabo Frio upwelling is of lesser importance due to the moderate content of nutrients in the waters (phosphorus: $1 \mu \mathrm{mol} \mathrm{L}{ }^{-1}$; nitrogen: 5-10 $\mu \mathrm{mol} \mathrm{L}^{-1}$ ). However, it exceeds many times the nutrient concentration in the Brazil Current (nitrate < $1 \mu \mathrm{mol} \mathrm{L}-1$; phosphate $<0.2 \mu \mathrm{mol} \mathrm{L}^{-1}$ ).

In the present work the objective was to test the hypothesis of copper as an inhibitor factor for the primary production in waters of the upwelling region of Cabo Frio.

\section{Experimental}

\section{Sampling}

Water samples used in the present study were collected on two different occasions. In the first campaign, samples were collected only from 2 stations (stations 1 and 2 described below) out of the three initially planned, and besides the basic physical and chemical data listed below, the total copper (II) concentration was also measured. The stormy sea on this occasion coupled with the poor conditions on board the ship Miguel dos Santos hindered more complex sampling manipulations. In the second sampling the Astro Garoupa ship equipped with an appropriate container for advanced chemical work was utilized and samplings occurred at three planned stations (station 1: $23^{\circ} 01^{\prime} 12^{\prime \prime} \mathrm{S} / 42^{\circ} 00^{\prime} 56^{\prime \prime} \mathrm{W}$; station 2: $23^{\circ} 02^{\prime} 00^{\prime \prime}$ $\mathrm{S} / 42^{\circ} 00^{\prime} 28^{\prime \prime} \mathrm{W}$; station 3: $23^{\circ} 04^{\prime} 48^{\prime \prime} \mathrm{S} / 42^{\circ} 00^{\prime} 18^{\prime \prime} \mathrm{W}$ ). Water samples were collected from $5 \mathrm{~m}, 20 \mathrm{~m}, 30 \mathrm{~m}$ and 50 $\mathrm{m}$ depth by using pre-cleaned Teflon coated 5 L Go-Flo sampling bottles and a polyethylene coated cable. Sampling depths were selected to include the photic zone and the zone immediately below that.

Samples were transferred to storage bottles under nitrogen pressure and in a plastic foil hood. In the first campaign temperature, $\mathrm{pH}$ and net primary production (NPP) were determined on board and the samples were filtered immediately after sampling. Samples for ammonia and oxygen determination were fixed on board as recommended in the classical methodologies and the spectrophotometric determination of ammonia, as well as the titration for dissolved oxygen were carried out within a few hours after sampling. Other nutrient concentrations were also determined on the same day after sampling and samples were preserved under ice or in a freezer. For total copper determination, waters were transferred as above to clean $1 \mathrm{~L}$ Teflon bottles, acidified to $\mathrm{pH} 2$ with $\mathrm{HNO}_{3}$ and stored at $-20{ }^{\circ} \mathrm{C}$. In both sampling occasions there was full sun and very low wind velocity.

All material used for storage, filtration, extraction and measurement were tested for metal contamination and precleaned with successive treatments in Extran 5\% (v/v), $\mathrm{HNO}_{3}$ P.A. 1:1 (v/v), $\mathrm{HNO}_{3}$ P.A. 1:10 (v/v), $\mathrm{HNO}_{3}$ Supra Pur, Merck, 1:10 (v/v), and Milli-Q water. Clean polyethylene bags were used to enclose and protect sampling and storage bottles prior to and after sampling.

Temperature, salinity, $\mathrm{pH}$, dissolved oxygen, particulate matter, alkalinity, phosphate, nitrate, nitrite, ammonia, silicate, chlorophyll a, primary production and total $\mathrm{Cu}$ (II) were determined for all the samples. In the samples from the second campaign, the copper complex capacity and copper (I) concentration were also determined together with the above. The classical methods presented in Grasshoff et al. ${ }^{18}$ and in Strickland and Parsons ${ }^{19}$ were used for nutrient, chlorophyll a and dissolved oxygen analysis. Primary production was measured using the ${ }^{14} \mathrm{C}$ method of Steeman and Nielsen ${ }^{20}$ in which the water sample after being inoculated with labeled bicarbonate is incubated under controlled temperature and fixed light intensity over $4 \mathrm{~h}$, alkalinity was determined potentiometrically. Particulate matter was determined gravimetrically after filtration using $0.45 \mathrm{~mm}$ Millipore membrane filter.

\section{$\mathrm{Cu}$ (I) determination}

The procedure described by Moffet and $\mathrm{Zika}^{10}$ includes 
chelation of $\mathrm{Cu}$ (I) with 2,9-dimethyl-1,10 phenantroline and binding of $\mathrm{Cu}$ (II) with ethylenediamine, followed by extraction of the chelated $\mathrm{Cu}$ (I) with distilled methylene chloride (chromatographic grade submitted to sub-boiling distillation) and back extraction in $\mathrm{HNO}_{3}(10 \%-\mathrm{v} / \mathrm{v})$. Extractions providing a copper concentration factor of 500 were carried out in $1 \mathrm{~L}$ of seawater immediately after sampling. Separation funnels and all sample and reagent storage bottles were made of Teflon. All reagents were tested for blank; $\mathrm{HNO}_{3}$ (Merck Suprapur) and $\mathrm{NH}_{4} \mathrm{OH}$ (isothermically distillated) were used to adjust the $\mathrm{pH}$. The analytical determination of copper in the acid extract was performed in a Perkin Elmer AAS 1100 equipped with a graphite furnace HGA-300. The GF-AAS detection limit for copper was $1.7610^{-8} \mathrm{~mol} \mathrm{~L}^{-1}$ and the relative standard deviation was of the order of $10 \%(n=2)$; a standard calibration curve was used for quantification.

\section{Total $\mathrm{Cu}(\mathrm{II})$ determination}

Adsorption stripping voltammetry was used following the method reported by van den Berg, ${ }^{21}$ which is based on the adsorption of the copper-8-hydroxyquinoline on the hanging drop mercury electrode (HMDE). Unfiltered samples for $\mathrm{Cu}$ (II) determination were stored frozen at $-20{ }^{\circ} \mathrm{C}$ (after acidification to $\mathrm{pH} 2$ with $\mathrm{HNO}_{3}$ (Merck Suprapur). Unfiltered samples were used considering the usually low particulate content of the studied waters and to avoid contamination. The optimized procedure follows: $10 \mathrm{~g}$ of sample was weight directly into a Teflon polarographic cell; the $\mathrm{pH}$ was adjusted around 7.5-7.7 by adding pre-cleaned HEPES $0.01 \mathrm{~mol} \mathrm{~L}^{-1}$ and 8-hydroxyquinoline was added to give a final concentration of $8 \times 10^{-6} \mathrm{~mol} \mathrm{~L}^{-1}$. Measurements were performed in a PAR 384B polarographic analyser equipped with a HMDE PAR 303A, using the following conditions: drop size large; $-0.200 \mathrm{~V}$ initial potential; $-0.550 \mathrm{~V}$ final potential; $0.025 \mathrm{~V}$ pulse height; $0.2 \mathrm{~s}$ pulse time; $10 \mathrm{mV} \mathrm{s}^{-1}$ scan rate; 15 min de-aeration time; mild stirring; 30-60 s adsorption time. Copper peak potential appeared at -0.400 V. All samples were run in triplicate and quantification was made by the standard addition method which yielded standard curves with $0.9987<\mathrm{R}<0.9999$. The detection limit was $0.23 \mathrm{nmol} \mathrm{L}^{-1}$ and the standard deviation $(\mathrm{n}=3)$ was $5.2 \%$ at $1.3 \mathrm{nmol} \mathrm{L}^{-1}$ concentration level.

\section{$\mathrm{Cu}$ (II) complexing capacity determination}

The method reported by Zhou and Wangersky ${ }^{22}$ was used for the determination of $\mathrm{Cu}$ (II) complexing capacity. Copper up to $1 \mu \mathrm{mol} \mathrm{L}^{-1}$ final concentration, was added to
$400 \mathrm{~mL}$ of freshly collected seawater sample. After $2 \mathrm{~h}$ of equilibration time the whole volume was injected into a pre-cleaned Sep-Pak $\mathrm{C}_{18}$ cartridge. The cartridges were then stored at $-20{ }^{\circ} \mathrm{C}$ before eluting the copper complexes according to polarity by using $5.0 \mathrm{~mL}$ of methanol followed by $10.0 \mathrm{~mL}$ of methanol/water $1: 1(\mathrm{v} / \mathrm{v})$.

\section{Results and Discussion}

Results are reported in Tables 1 and 2. Figure 1 shows the temperature/salinity diagrams that aid in understanding the complex oceanographic situation present during both campaigns. The coastal region of Rio de Janeiro is in the domain of the Brazil Current (BC), characterized by warm $\left(21->24{ }^{\circ} \mathrm{C}\right)$ and saline $(36.00-36.50)$ waters. The upwelling waters in Cabo Frio are less saline (35.00-35.50) and colder $\left(<18{ }^{\circ} \mathrm{C}\right.$ in the surface to $<15{ }^{\circ} \mathrm{C}$ at $\left.50 \mathrm{~m}\right)$, therefore, the temperature-salinity diagram indicates mixing between the two water masses as well as the prevailing conditions (for instance, upwellingdownwelling). It is evident from the data that a full upwelling event was not prevailing at any time. In the first sampling waters at the surface were in the temperature range of the Brazil Current but less saline, while at depths,
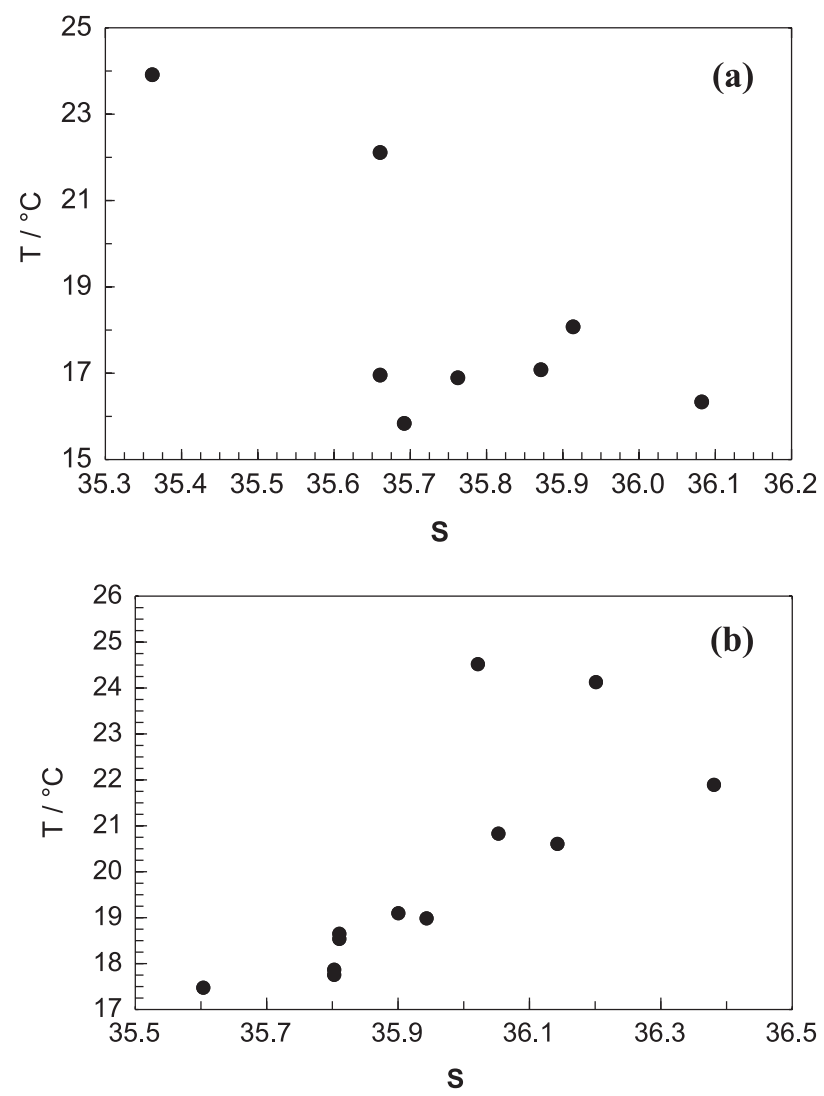

Figure 1. Temperature/Salinity diagram: (a) data for the first sampling, (b) data for the second sampling. 
Table 1. Physical and chemical data obtained in the first (A) and second (B) sampling campaigns

\begin{tabular}{|c|c|c|c|c|c|c|c|c|c|c|c|c|c|c|}
\hline $\begin{array}{l}\text { Station/ } \\
\text { deep }\end{array}$ & $\begin{array}{c}\mathrm{T} \\
\left({ }^{\circ} \mathrm{C}\right)\end{array}$ & $\begin{array}{c}\text { Salinity } \\
\text { SSU }\end{array}$ & $\mathrm{pH}$ & $\begin{array}{c}\mathrm{O}_{2 \text { dis }} \\
\left(\mathrm{mLL}^{-1}\right)\end{array}$ & $\begin{array}{l}\mathrm{PM} \\
\left(\mathrm{mg} \mathrm{L}^{-1}\right)(\mathrm{x} 1\end{array}$ & $\begin{array}{c}\text { Alk. } \\
10^{-3} \mathrm{~mol} \mathrm{~L}\end{array}$ & $\begin{array}{c}\mathrm{PO}_{4}-\mathrm{P} \\
\left.\mathrm{L}^{-1}\right)\left(\mu \mathrm{mol} \mathrm{L}^{-1}\right.\end{array}$ & $\begin{array}{r}\mathrm{NO}_{2}-\mathrm{N} \\
\left.{ }^{-1}\right)\left(\mu \mathrm{mol} \mathrm{L}{ }^{-1}\right)\end{array}$ & $\begin{array}{c}\mathrm{NO}_{3}-\mathrm{N} \\
\left(\mu \mathrm{mol} \mathrm{L} \mathrm{L}^{-1}\right)\end{array}$ & $\begin{array}{c}\mathrm{NH}_{4}-\mathrm{N} \\
\left(\mu \mathrm{mol} \mathrm{L}^{-1}\right)\end{array}$ & $\begin{array}{c}\mathrm{SiO}_{4}-\mathrm{Si} \\
\left(\mu \mathrm{mol} \mathrm{L}^{-1}\right)\end{array}$ & $\begin{array}{c}\mathrm{NPP} \\
\left(\mathrm{mgC} \mathrm{m}^{3} \mathrm{~h}^{-1}\right)\end{array}$ & $\begin{array}{c}\text { Chl a } \\
\left(\mathrm{mg} \mathrm{m}^{-3}\right)\end{array}$ & $\begin{array}{l}{\left[\mathrm{CO}_{2}\right]_{\mathrm{aq}}} \\
\left(\mu \mathrm{mol} \mathrm{L} \mathrm{L}^{-1}\right)\end{array}$ \\
\hline $1 \mathrm{~A} / 5 \mathrm{~m}$ & 23.92 & 35.36 & 8.12 & 5.53 & n.d & 2.23 & 0.5 & 0.23 & 0.63 & 1.46 & 2.08 & 4.79 & 1.47 & \\
\hline $1 \mathrm{~A} / 20 \mathrm{~m}$ & 18.10 & 35.91 & 8.14 & 5.21 & 9.95 & 2.24 & 0.50 & 0.65 & 3.66 & 2.23 & 2.68 & 0.45 & 0.56 & \\
\hline $1 \mathrm{~A} / 30 \mathrm{~m}$ & 16.38 & 36.06 & 8.14 & 4.87 & 5.78 & 2.25 & 0.62 & 0.82 & 6.98 & 1.42 & 3.18 & 0.97 & 0.46 & \\
\hline $1 \mathrm{~A} / 50 \mathrm{~m}$ & 15.88 & 35.69 & 8.13 & 4.58 & 9.35 & 2.22 & 0.52 & 0.68 & 7.14 & 2.68 & 3.18 & 0.38 & 0.45 & \\
\hline $2 \mathrm{~A} / 5 \mathrm{~m}$ & 22.14 & 35.66 & 8.25 & 5.55 & 7.96 & 2.23 & 0.20 & 0.07 & 0.15 & 1.76 & 1.69 & 5.10 & 1.32 & \\
\hline $2 \mathrm{~A} / 20 \mathrm{~m}$ & 17.14 & 35.87 & 8.12 & 4.73 & 9.97 & 2.25 & 0.50 & 0.83 & 4.26 & 1.97 & 2.48 & 0.51 & 0.61 & \\
\hline $2 \mathrm{~A} / 30 \mathrm{~m}$ & 16.98 & 35.66 & 8.09 & 5.13 & 8.47 & 2.22 & 0.58 & 0.84 & 5.01 & 2.23 & 3.18 & 0.01 & 0.95 & \\
\hline $2 \mathrm{~A} / 50 \mathrm{~m}$ & 16.92 & 35.76 & 8.09 & 4.82 & 11.13 & 2.25 & 0.70 & 0.80 & 6.72 & 1.44 & 2.58 & 0.34 & 0.33 & \\
\hline $1 \mathrm{~B} / 5 \mathrm{~m}$ & 20.66 & 36.14 & 8.32 & 5.15 & 18.47 & 2.23 & 0.64 & 0.42 & 1.38 & 2.80 & 5.20 & 1.03 & 0.14 & 8.94 \\
\hline $1 \mathrm{~B} / 20 \mathrm{~m}$ & 17.92 & 35.80 & 8.41 & 4.67 & 18.77 & 2.23 & 0.76 & 0.24 & 6.74 & 1.31 & 7.16 & 0.42 & 0.08 & 6.91 \\
\hline $1 \mathrm{~B} / 30 \mathrm{~m}$ & 17.80 & 35.80 & 8.33 & 4.50 & 17.47 & 2.05 & 0.64 & 0.18 & 7.07 & 1.79 & 5.98 & 0.33 & 0.07 & 7.97 \\
\hline $1 \mathrm{~B} / 50 \mathrm{~m}$ & 17.50 & 35.60 & 8.53 & 4.36 & 17.10 & 1.95 & 0.76 & 0.15 & 7.09 & 2.33 & 5.59 & 0.15 & 0.05 & 4.25 \\
\hline $2 \mathrm{~B} / 5 \mathrm{~m}$ & 24.14 & 36.20 & 8.44 & 5.27 & 17.22 & 2.24 & 0.37 & 0.07 & 0.33 & 1.57 & 3.53 & 1.84 & 0.24 & 5.44 \\
\hline $2 \mathrm{~B} / 20 \mathrm{~m}$ & 20.86 & 36.05 & 8.40 & 4.38 & 16.57 & 2.10 & 0.63 & 0.20 & 2.40 & 1.86 & 3.92 & 1.10 & 0.21 & 6.24 \\
\hline $2 \mathrm{~B} / 30 \mathrm{~m}$ & 19.00 & 35.94 & 8.35 & 4.34 & 13.71 & 2.13 & 0.53 & 0.13 & 5.22 & 2.13 & 3.82 & 0.19 & 0.12 & 7.65 \\
\hline $2 \mathrm{~B} / 50 \mathrm{~m}$ & 18.56 & 35.81 & 8.26 & 4.30 & 13.40 & 2.23 & 0.66 & 0.01 & 7.17 & 1.78 & 6.18 & 0.14 & 0.08 & 10.54 \\
\hline $3 \mathrm{~B} / 5 \mathrm{~m}$ & 24.56 & 36.02 & 8.34 & 5.46 & 16.72 & 2.22 & 0.25 & $>\mathrm{DL}$ & 0.21 & 1.49 & 3.04 & 1.11 & 0.30 & 7.28 \\
\hline $3 \mathrm{~B} / 20 \mathrm{~m}$ & 21.90 & 36.38 & 8.34 & 5.24 & 12.67 & 2.06 & 0.31 & $>\mathrm{DL}$ & 0.02 & 1.72 & 2.55 & 0.31 & 0.10 & 7.03 \\
\hline $3 \mathrm{~B} / 30 \mathrm{~m}$ & 19.12 & 35.90 & 8.31 & 5.17 & 11.80 & 2.07 & 0.60 & 0.33 & 4.35 & 1.85 & 4.61 & 0.31 & 0.22 & 8.28 \\
\hline $3 \mathrm{~B} / 50 \mathrm{~m}$ & 18.66 & 35.81 & 8.60 & 4.49 & 11.72 & 2.24 & 0.61 & 0.05 & 4.81 & 2.65 & 3.82 & 0.11 & 0.11 & 3.91 \\
\hline
\end{tabular}

PM: particulate matter; Chl a: chlorophyll a; SSU: standard salinity units; NPP: net primary production; DL $\left(\mathrm{NO}_{2}-\mathrm{N}\right): 0.01 \mu \mathrm{mol} \mathrm{L}{ }^{-1}$.

Table 2. Total copper (II) concentration and standard deviation in the first (A) and second (B) samplings; $\mathrm{Cu}(\mathrm{I})$, standard deviation and chelated copper in the second sampling

\begin{tabular}{|c|c|c|c|c|c|c|c|}
\hline $\begin{array}{l}\text { Station/ } \\
\text { deep }\end{array}$ & $\begin{array}{c}\mathrm{Cu}(\mathrm{II}) \\
\left.(\mathrm{nmol} \mathrm{L})^{-1}\right)\end{array}$ & $\begin{array}{c}\mathrm{Cu}(\mathrm{I}) \\
\left(\mathrm{nmol} \mathrm{L} \mathrm{L}^{-1}\right)\end{array}$ & $\begin{array}{l}\mathrm{Cu}(\mathrm{II}) \text { chelate } \\
\left(\mathrm{nmol} \mathrm{L} \mathrm{L}^{-1}\right)\end{array}$ & thanol & $\begin{array}{l}\mathrm{Cu}(\mathrm{II}) \text { chelate-me } \\
\left(\mathrm{nmol} \mathrm{L} \mathrm{L}^{-1}\right)\end{array}$ & $\begin{array}{l}\text { nol/water } \\
(\%)^{\mathrm{a}}\end{array}$ & $\begin{array}{c}\text { Total } \mathrm{Cu}(\mathrm{II}) \text { Bound } \\
(\%)^{\mathrm{a}}\end{array}$ \\
\hline $1 \mathrm{~A} / 5 \mathrm{~m}$ & $2.80(0.01)$ & & & & & & \\
\hline $1 \mathrm{~A} / 20 \mathrm{~m}$ & $1.57(0.06)$ & & & & & & \\
\hline $1 \mathrm{~A} / 30 \mathrm{~m}$ & $1.67(0.06)$ & & & & & & \\
\hline $1 \mathrm{~A} / 50 \mathrm{~m}$ & $5.67(0.05)$ & & & & & & \\
\hline $2 \mathrm{~A} / 5 \mathrm{~m}$ & $6.19(0.09)$ & & & & & & \\
\hline $2 \mathrm{~A} / 20 \mathrm{~m}$ & $3.23(0.22)$ & & & & & & \\
\hline $2 \mathrm{~A} / 30 \mathrm{~m}$ & $2.54(0.19)$ & & & & & & \\
\hline $2 \mathrm{~A} / 50 \mathrm{~m}$ & $2.00(0.10)$ & & & & & & \\
\hline $1 \mathrm{~B} / 5 \mathrm{~m}$ & $2.25(0.15)$ & $0.085(0.002)$ & $1.90(0.01)$ & 83 & $0.40(0.01)$ & 17 & 100 \\
\hline $1 \mathrm{~B} / 20 \mathrm{~m}$ & $2.70(0.12)$ & $0.139(0.002)$ & $1.80(0.01)$ & 78 & $0.50(<0.01)$ & 22 & 85 \\
\hline $1 \mathrm{~B} / 30 \mathrm{~m}$ & $2.56(0.45)$ & $0.073(0.002)$ & $1.90(<0.01)$ & 79 & $0.50(<0.01)$ & 21 & 94 \\
\hline $1 \mathrm{~B} / 50 \mathrm{~m}$ & $3.16(0.16)$ & $0.044(0.002)$ & $0.70(<0.01)$ & 78 & $0.20(<0.01)$ & 22 & 28 \\
\hline $2 \mathrm{~B} / 5 \mathrm{~m}$ & $3.29(0.13)$ & $0.065(0.001)$ & $1.30(<0.01)$ & 59 & $0.90(<0.01)$ & 41 & 67 \\
\hline $2 \mathrm{~B} / 20 \mathrm{~m}$ & $3.77(0.02)$ & $0.044(0.001)$ & $1.30(<0.01)$ & 54 & $1.10(<0.01)$ & 46 & 64 \\
\hline 2B/30m & $5.71(0.05)$ & $0.144(0.003)$ & $1.80(<0.01)$ & 82 & $0.40(<0.01)$ & 18 & 38 \\
\hline $2 \mathrm{~B} / 50 \mathrm{~m}$ & $6.47(0.03)$ & $0.173(0.003)$ & $1.30(<0.01)$ & 68 & $0.60(<0.01)$ & 32 & 29 \\
\hline $3 \mathrm{~B} / 5 \mathrm{~m}$ & $1.32(0.08)$ & $0.198(0.001)$ & $1.20(<0.01)$ & 71 & $0.50(<0.01)$ & 29 & 100 \\
\hline $3 \mathrm{~B} / 20 \mathrm{~m}$ & $2.31(0.11)$ & $0.035(0.001)$ & $1.50(<0.01)$ & 88 & $0.20(<0.01)$ & 12 & 74 \\
\hline $3 \mathrm{~B} / 30 \mathrm{~m}$ & $3.45(0.23)$ & $0.115(0.002)$ & $1.00(<0.01)$ & 83 & $0.20(<0.01)$ & 17 & 35 \\
\hline $3 \mathrm{~B} / 50 \mathrm{~m}$ & $6.18(0.27)$ & $0.156(0.001)$ & $1.70(<0.01)$ & 61 & $1.10(<0.01)$ & 39 & 45 \\
\hline
\end{tabular}

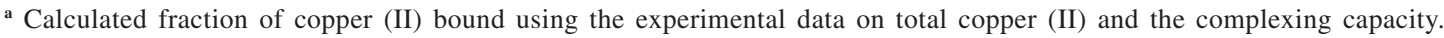

temperatures were in the range of the SACW but salinities were higher. In both samplings, colder waters penetrated the photic zone (1\% of light extinction at $20-25 \mathrm{~m}$ as estimated from Secchi disc). The relatively low salinities at the surface in the first sampling can be explained by the presence of surface shelf waters $\left(>18^{\circ} \mathrm{C}\right.$ and $34-36$, caused by the mixing of coastal and tropical waters) as reported for other occasions by Valentin, ${ }^{23}$ Mendonça ${ }^{24}$ and Moreira da Silva. ${ }^{25,26}$ The presence of waters with temperatures as low as $15-16^{\circ} \mathrm{C}$ at $50 \mathrm{~m}$ indicate a recent event of upwelling while the intermediate temperatures are deriving from a mixture of water masses that is common in periods following termination of upwelling.

In the second sampling, the T/S diagram indicates the 
proximity of the Brazil Current to the coast and a complex mixture of BC and SACW. The process of upwelling and downwelling generates large horizontal and vertical heterogeneity in the area, whereby the water masses that are subsiding carry materials produced in the surface to greater depths. The lower temperatures and salinities in profile 1 indicate penetration of colder waters through the bottom and mixing. This complexity of waters in a process of vertical and horizontal movement affect the measured chemical properties and produce scattered depth profiles with very distinct features at each sampling station, as discussed below.

In both samplings the low dissolved oxygen values observed in surface waters in comparison with those encountered in typical upwelling events $\left(\sim 6 \mathrm{~mL} \mathrm{~L}^{-1}\right.$ in the surface and $4 \mathrm{~mL} \mathrm{~L}^{-1}$ at depth) are indicative of a period after a recent upwelling. In these periods production is low but there is still an elevated number of cells and organic matter to decompose. The N/P ratio, which was between 9.2 (surface) and $20.2(50 \mathrm{~m})$ in the first sampling and between 5.3 (surface) and $14(30 \mathrm{~m})$ in the second sampling, confirms earlier observation ${ }^{27}$ of nitrogen limitations in the area. Phosphate correlates directly with silicate and both nutrients are inversely correlated to temperature as expected, since the colder waters are the main source of new N, P and $\mathrm{Si}$ in the area.

Using $\mathrm{pH}$, alkalinity and the temperature corrected ionization constants for the carbonic acid in seawater was calculated $\mathrm{CO}_{2 \text { (aq) }}$ for the second sampling (see Table 1). The $\mathrm{CO}_{2(\text { aq })}$ and $\mathrm{O}_{2 \mathrm{dis}}$ depth profiles also point out the heterogeneity of the system. At station 1 production and heterotrophic respiration (possibly also due to the accumulation of land organic material) are both occurring more intensively at the surface while at stations 2 and 3 the $\mathrm{CO}_{\text {2(aq) }}$ maximum is at the bottom of the photic zone.

The high $\mathrm{Cu}$ (II) values at $5 \mathrm{~m}$ depth in the first sampling may reflect the input of land derived material (possibly also from Guanabara Bay and from the north). The T/S values for these samples show high temperature waters with unusually low salinity that can only be explained as resulting from continental drainage as discussed above. For the second sampling there is, in general, an increasing $\mathrm{Cu}$ (II) concentration with depth. There are large concentration variations between samplings in both stations 1 and 2 . At $50 \mathrm{~m}$, concentrations were in the range between 2 and 6.5 $\mathrm{nmol} \mathrm{L} \mathrm{L}^{-1}$. Kremling and Wagener ${ }^{17}$ reported concentrations of 1.3 to $4.5 \mathrm{nmol} \mathrm{L}^{-1}$ for the same region.

$\mathrm{Cu}$ (I) was found as 2 to $15 \%$ of the total $\mathrm{Cu}$ (II), in agreement with the levels reported by Moffet and Zika, ${ }^{10}$ but only in stations 1 and 3 were the concentrations higher at the surface where photochemical reactions are more intense. The depth profiles were also very irregular when compared to those reported by the Moffet and Zika, ${ }^{10}$ who found a smooth decrease in $\mathrm{Cu}$ (I) from surface to the bottom of the photic zone $(200 \mathrm{~m})$ in the coastal region of Florida. The irregular profiles were ascribed to the complex distribution and mixture of water masses prevailing in the sampling period. Mixing processes and the formation of vortices during subsidence periods ${ }^{28}$ increasing the vertical transport of material may explain the values of $\mathrm{Cu}$ (I) below the euphotic zone ( $25 \mathrm{~m}$ depth). A production of $\mathrm{Cu}$ (I) from biological processes cannot be ruled out although no relationship has been found between $\mathrm{Cu}$ (I) concentration and the chemical indicators of biological activity observed here.

Complexing capacities varied from $0.90 \mathrm{nmol} \mathrm{L}^{-1}$ to $2.80 \mathrm{nmol} \mathrm{L}^{-1}$ and since the samples were unfiltered, the values also include binding sites in the particulate phase. Binding sites of low polarity are predominant making up more than $60 \%$ of the total complexing capacity. The concentration of copper bound was estimated from the complexing capacities and varied from $100 \%$ at the surface to $28-45 \%$ at $50 \mathrm{~m}$.

Although concentration depth profiles as stated above were very different in the observed stations, the whole set of data for each sampling were evaluated in order to improve the statistical significance of the conclusions. The statistically significant $(\mathrm{p} \leq 0.05)$ Pearson correlation coefficients for the second sampling are displayed in Table 3. Trends observed for the first sampling were strongly biased by the values from $5 \mathrm{~m}$ depth samples apparently influenced by coastal water inputs

Nitrate, phosphate and silicate concentrations are obviously dependent on the upwelling contribution as they appear in close association to low temperatures and low salinity. In both the first and second sampling, the rate of primary production was strongly but negatively correlated to nutrient species, inclusively to the production potential of the water masses as represented by the ratio $\mathrm{N}_{\mathrm{T}} / \mathrm{P}$. On the other hand, the ratio NPP/Chl a, which is used to normalize the production data to the initial standing biomass, correlates significantly to the fraction of bound copper. Excellent correlations $(r=0.95 ; \mathrm{p} \leq 0.05)$ between these two variables are found in station 2 and 3 evaluated separately. When evaluating the effect of the complexing capacity normalized to the concentration of nitrogen species ( $\mathrm{N}$ is the limiting nutrient in the observed system) on the NPP/Chl a significant correlations were obtained using the whole set of data $(r=0.73 ; p<0.05)$ as well as using data from individual profiles $(\mathrm{S} 1 \mathrm{r} \mathrm{r}=1.00, \mathrm{p}<0.05$; $\mathrm{S} 2: \mathrm{r}=0.96, \mathrm{p}<0.05 ; \mathrm{S} 3: \mathrm{r}=0.94, \mathrm{p}<0.06)$. These results give a strong indication that "free" copper may play an 
Table 3. Statistically significant Pearson correlation coefficients $(\mathrm{p}<0.05)$ for data from the second sampling

\begin{tabular}{|c|c|c|c|c|c|c|c|c|c|c|c|c|}
\hline & $\mathrm{T}$ & S & $\mathrm{O}_{2}$ & $\mathrm{PO}_{4}$ & $\mathrm{NO}_{3}$ & $\mathrm{SiO}_{2}$ & NPP & Chl a & $\mathrm{Cu}(\mathrm{II})$ & $\% \mathrm{Cu}_{\mathrm{B}}$ & NPP/Chl a & $\mathrm{N}_{\mathrm{T}}$ \\
\hline $\mathrm{T}$ & & 0.76 & 0.77 & -0.88 & -0.92 & -0.72 & 0.80 & 0.81 & & & & -0.95 \\
\hline S & 0.76 & & 0.67 & -0.73 & -0.89 & -0.68 & & & & & & -0.89 \\
\hline $\mathrm{O}_{2 \text { dis }}$ & 0.77 & 0.67 & & -0.71 & -0.80 & & & 0.65 & -0.67 & & & -0.81 \\
\hline $\mathrm{PO}_{4}-\mathrm{P}$ & -0.88 & -0.73 & -0.71 & & 0.81 & 0.84 & & -0.64 & & & & 0.86 \\
\hline $\mathrm{NO}_{3}-\mathrm{N}$ & -0.92 & -0.89 & -0.80 & 0.81 & & 0.79 & -0.71 & -0.71 & & & & 0.99 \\
\hline $\mathrm{SiO}_{2}$ & -0.72 & -0.68 & & 0.84 & 0.79 & & & -0.58 & & & & 0.78 \\
\hline NPP & 0.80 & & & & -0.71 & & & 0.73 & & & & -0.72 \\
\hline Chl a & 0.81 & & 0.65 & -0.64 & -0.71 & -0.58 & 0.73 & & & & & -0.73 \\
\hline $\mathrm{Cu}(\mathrm{II})$ & & & -0.67 & & & & & & & & -0.58 & \\
\hline$\% \mathrm{Cu}_{\mathrm{B}}$ & & & & & & & & & & & 0.68 & \\
\hline NPP/Chl a & & & & & & & & & -0.58 & 0.68 & & \\
\hline $\mathrm{N}_{\mathrm{T}}$ & -0.95 & -0.89 & -0.81 & 0.86 & 0.99 & 0.78 & -0.72 & -0.73 & & & & \\
\hline
\end{tabular}

inhibiting role in phytoplankton growth in the observed waters and that biological conditioning, indeed, must take place before available nutrients can be used.

The ratio of total copper (II) to particulate matter also appears to be relevant in the control of primary production $(\mathrm{r}=0.70, \mathrm{p}<0.05$ for $\mathrm{Cu}(\mathrm{II}) / \mathrm{PM} v s . \mathrm{NPP} / \mathrm{Chla})$. The adsorption tendency of copper on natural particles of either organic and inorganic origin is well known ${ }^{29,30}$ (including surface complex formation) and therefore, the greater availability of particles should result in increased removal of copper ions from solution phase and in the decrease of its toxicity to the phytoplankton.

Alkalinity and $\mathrm{Cu}$ (I) showed no significant correlations with the other measured components.

\section{Conclusions}

Although samplings did not take place during a maximum upwelling period but during a stage of complex distribution of water masses, the results obtained so far, indicate the influence of copper (II) speciation on primary production in the region. The statistically significant relationship given here are the first ones reported since the work by Barber and Ryther ${ }^{4}$ for field conditions whereas most other copper toxicity related experiments have been performed in laboratory under controlled conditions.

The presence of a significant steady-state level of $\mathrm{Cu}$ (I) in seawater has been attributed to direct $\mathrm{Cu}$ (II) photochemical reactions or to reduction by hydrogen peroxide $^{31}$ following stabilization by chloride complexation. In the observed samples copper (I) was present at measurable concentrations, however, there were no indication that its production reduced the copper binding capacity or influenced the NPP of the studied waters.

The inverse relation between primary production and nutrient species, especially of nitrogen (the principal limiting nutrient in the region), is a very strong indication that there are other important limiting factors. Besides inorganic species of copper (II), iron deficiency could play some role although the proximity to land and therefore constant inputs of iron from the continent should rule out this aspect. Nonetheless, additional investigations should be carried out on iron speciation as related to production in these waters.

\section{Acknowledgements}

The authors are grateful to $\mathrm{CNPq}$ for the financial support and to PETROBRAS that provided the ship facility.

\section{References}

1. Sunda, W.G.; Guillard, R.R.L.; J. Mar. Res. 1976, 34, 511.

2. Brand, L.E.; Sunda, W.G.; Guillard, R.R..L.; J. Exp. Mar. Biol. Ecol. 1986, 96, 225.

3. Eriksen, R.S.; Mackey, D.J.; van Dam, R.; Nowak, B.; Mar. Chem. 2001, 74, 99.

4. Barber, T.B.; Ryther, J.H.; J. Exp. Mar. Biol. Ecol. 1969, 3, 191.

5. Barber, R.T.; Dugdale, R.C.; MacIsaac, J.J.; Smith, R.L.; Inv. Pesq. 1971, 35, 171

6. Barber, R.T. In Trace Metals and Metal-Organic Interaction in Natural Waters; Singer, P. ed.; Ann Arbor Science: Ann Arbor, 1973, pp. 321-328.

7. Jackson, G.A.; Morgan. J.J.; Limnol Oceanogr. 1978, 23, 268.

8. Gerringa, L.J.A.; Rijstenbil, J.W.; Poortvliet, T.C.W.; van Drie, J.; Schot, M.C.; Aquat. Toxicol. 1995, 31, 77.

9. Rijstenbil, J.W.; Derksen, J.W.M.; Gerringa, L.J.A.; Pootvliet, T.C.W.; Sandee, A; van den Berg, M.; van Drie, J.; Wijnholds, J.A.; Mar. Biol. 1994, 119, 583

10. Moffet, J.W.; Zika, R.G.; Geochim Cosmochim. Acta 1988 , $52,1849$.

11. André, D.L.; MSc. Dissertation, Universidade Federal Fluminense, Rio de Janeiro, Brazil, 1990. 
12. Pires-Vanin, A.M.S.; Publ.Esp. Inst. Oceangr. 1993, 10, 217.

13. Miranda, L.B.; Katsuragawa, M.; Publ. Esp. Inst. Oceanogr. 1991, 8,1 .

14. Rodrigues, R.F.; Publ. Inst. Pesq. Mar. 1977, 115, 1.

15. Valentin, J.L.; Hidrobiologia 1984a, 113, 183.

16. Valentin, J.L.; Mar. Biol. 1984b, 82, 259.

17. Kremling, K.; Wagener, A. de L.R.; Abstract of the Rio Conference on the Chemistry of Tropical Marine Systems, Rio de Janeiro, Brazil, 1987.

18. Grasshoff, K.; Ehrhardt, M.; Kremiling, K.; Methods of Seawater Analysis, $2^{\text {nd }}$ ed., Verlag Chemie: Kiel, 1983.

19. Strickland, J.D.H.; Parsons, T.R.; Bull. Fish. Res. Board. Can. 1972, 167, 311

20. Steeman, N. In The Sea; Hill, M.N., ed., Interscience Publ: New York, 1952, vol. II.

21. van den Berg, C.M.G.; Mar. Chem. 1986, 19, 111.

22. Zhou, X.; Wangersky, P.J.; Mar. Chem. 1989, 26, 21.
23. Valentin, J.L.; Mar. Biol. 1984, 82, 259

24. Mendonça, C.F.; Publ. Inst. Pesq. Mar. 1977, 102, 1.

25. Moreira da Silva, P.C.; Publ. Inst. Pesq. Mar. 1968a, 12, 1.

26. Moreira da Silva, P.C.; Publ. Inst. Pesq. Mar. 1968b, 20, 1.

27. Gonzalez-Rodriguez ,E.; Rev. Brasil. Biol. 1991, 51, 471

28. Valentin, J.L.; Monteiro-Ribas, W.; Mureb, A.; Pessoti, E.; Publ. Inst. Pesq. Mar. 1976, 97, 1

29. Stumm, W.; Morgan, J.J.; Aquatic Chemistry, $3^{\text {rd }}$ ed., Wiley: New York, 1996.

30. Andrade, W.; Wagener, A de L. R.; Cien. Cult. 1997, 49, 48.

31. Moffet, J.W.; Zika, R.G. In Photochemistry of Environmental Aquatic Systems; Zika, R.G.; Cooper, W.J., eds.; Adv. Chem. Ser. 327; Amer. Chem. Soc.: Washington, 1987.

Received: October 24, 2002

Published on the web: September 25, 2003 